The author(s) shown below used Federal funds provided by the U.S. Department of Justice and prepared the following final report:

Document Title: The Reporting of Domestic Violence and Sexual Assault by Nonstrangers to the Police

Author(s): $\quad$ Richard Felson, Paul-Philippe Paré

Document No.: 209039

Date Received: $\quad$ March 2005

Award Number: $\quad$ 2003-IJ-CX-1010

This report has not been published by the U.S. Department of Justice. To provide better customer service, NCJRS has made this Federallyfunded grant final report available electronically in addition to traditional paper copies.

Opinions or points of view expressed are those of the author(s) and do not necessarily reflect the official position or policies of the U.S. Department of Justice. 
FINAL REPORT

GRANT NO. 2003-IJ-CX-1010

\title{
THE REPORTING OF DOMESTIC VIOLENCE AND SEXUAL ASSAULT BY NONSTRANGERS TO THE POLICE *
}

\author{
Richard Felson \\ Department of Sociology \\ The Pennsylvania State University \\ 1012 Oswald Tower \\ University Park, PA 16802 \\ rbf7@psu.edu \\ \& \\ Paul-Philippe Paré \\ Department of Sociology \\ The Pennsylvania State University \\ 211 Oswald Tower, \\ University Park, PA 16802 \\ paul-philippe_pare@usa.com
}

* We thank Eric Baumer, Steve Messner, and Paul Amato for their comments on earlier drafts of this paper. 


\title{
THE REPORTING OF DOMESTIC VIOLENCE AND SEXUAL ASSAULT BY NONSTRANGERS TO THE POLICE
}

\begin{abstract}
We examine the effects of the gender of the victim and offender and their relationship to each other on whether sexual and physical assaults are reported to the police. We also examine the reasons victims give for not reporting assaults and whether reporting patterns have changed over time. The analyses are based on a sample of 6291 physical assaults and 1787 sexual assaults from The National Violence against Women Survey. The results suggest that victims are just as likely to report domestic assaults as they are to report assaults by other people they know. Male victims are particularly reluctant to report assaults by their intimate partners, while third parties are particular unlikely to report assaults by partners of either gender. Sexual assaults, particularly those that involve acquaintances, are less likely to be reported. These patterns have not changed since the 1960s.
\end{abstract}

KEYWORDS: Assault, Crime Reporting, Domestic Violence, Gender, Police, Sexual Assault 
The consensus among scholars and laypersons is that domestic violence and sexual assaults are hidden from society's view because most incidents are not reported to the police (e.g., Frieze \& Browne, 1989; Herzberger, 1996; Pagelow, 1984). Only “the tip of the iceberg” is observed -- the rest occurs "behind closed doors” (Straus, Gelles, \& Steinmetz, 1980). However, violence, in general, is often unreported (e.g. Gottfredson \& Gottfredson, 1980). Most fights involving young men, for example, never come to the attention of the police. It is important, therefore, to determine whether domestic violence and sexual assaults are less likely than other forms of violence to be reported to the police.

These comparisons permit an examination of whether there are special factors that inhibit the reporting of domestic violence and sexual assaults. If one wants to institute policies that encourage the reporting of assaults it is useful to determine the types of assaults that are unreported and the reasons they are not reported. For example, do women assaulted by their husbands have special reasons for not reporting or are their concerns similar to those of any victim of violent crime? Comparisons of reporting for different crimes are also relevant to discussions of the relative validity of official data for different offenses. It is generally assumed that official data is less useful for research on domestic and sexual assault than for other forms of violence because these crimes are more likely to be underreported. Finally, the comparisons are important because of their implications for deterrence. Violence is unlikely to come to the attention of the criminal justice system unless someone reports it. If domestic violence and sexual assault are less likely to be reported than other crime, and reporting is a deterrent, then offenders may be more likely to recidivate. 
Some scholars emphasize the role of gender in the reporting of domestic and sexual assault (e.g., Belknap, 2001; Dobash \& Dobash, 1998; Koss, Goodman, Browne, Fitzgerald, Keita, \& Russo, 1994). While they do not make explicit comparisons between different crimes they imply that domestic and sexual assaults against women are particularly likely to go unreported. Women's reluctance to report assaults by their male partners has been attributed to fear of reprisal, economic and psychological dependence, and anticipation that the police do not take these charges seriously (e.g., Frieze \& Brown, 1989; Pagelow, 1984). Women’s reluctance to report sexual assaults has sometimes been attributed to their lack of confidence in a criminal justice system that assigns blame to them rather than to offenders (e.g., Belknap, 2001; Williams, 1984). In general, these scholars emphasize gender discrimination in the criminal justice system and in the larger society.

A second approach to police notification focuses on the "relational distance" between the victim and offender (Black, 1976). The closer the relational distance between adversaries, the less likely it is for the legal system to intervene in disputes. Crimes involving adversaries in a close relationship are less likely to be reported, and the legal system is less responsive when they are reported. Thus, this perspective suggests that violent disputes between strangers are likely to activate a legal response, disputes between intimates or family members tend to be handled privately, and disputes between friends and acquaintances tend to fall somewhere in-between. Differences between domestic and stranger assault reflect a broader structural relationship between relational distance and the activation of law. In addition, the effects of relational distance should not depend on the gender of the offender and victim. 
Black’s (1976) approach would also predict gender effects on reporting. He argues that victims have less access to the law if they have lower status than their adversaries, i.e., “downward law” is greater than "upward law” (p. 21). If women have lower status than men, then men's assaults on women should be less likely to be reported than assaults involving other gender combinations. The argument implies a statistical interaction between the gender of offender and victim.

In the present study we use data from the National Violence against Women Survey to examine the effects of gender and social relationship on police notification for physical and sexual assault. We also examine the reasons victims give for not reporting the incident to the police. Finally, we examine whether police notification has changed over time. We first review the literatures on reporting physical assault and then review the separate literature on reporting sexual assault.

\section{REPORTING PHYSICAL ASSAULT}

The evidence as to whether domestic violence is less likely to be reported to the police than violence between strangers is mixed. Surveys of interpersonal violence suggest that the police are less likely to be notified when the offender is a partner or other family member than when the offender is a stranger (Block, 1974; Felson, 1996; Gartner \& Macmillan, 1995). For example, Felson (1996) examined police notification using data from a violence survey collected in 1980 in Albany, NY. The evidence suggested that violent disputes between people who knew each other, particularly couples, were less likely than disputes involving strangers to be reported to the police. In addition, violent 
disputes between men and women were much more likely to be reported to the police than violence between men.

Research based on the National Crime Victimization Survey (NCVS) has examined victim reporting separately from third party reporting (Felson, Messner, \& Hoskin, 1999). These analyses reveal the predicted effect of social relationship on third party reporting. Third parties were less likely to report assaults involving couples and friends than assaults involving strangers. They were also more likely to notify the police when a man attacked a woman (controlling for the victim-offender relationship). The study did not find the predicted effects of social relationship on victim reporting, however (see also Avakame, Fyfe, \& McCoy 1999; Bachman, 1998). Victims of domestic violence were just as likely as victims of stranger violence to call the police, regardless of gender. In addition, men were particularly unlikely to call the police when they were assaulted by another man.

Felson, Messner, Hoskin and Deane, (2002) analyzed the victim’s reasons for not reporting physical assaults using NCVS data. They found that victims of domestic violence were more likely to mention privacy concerns, fear of reprisal, and a desire to protect the offender than victims of stranger violence. Men were more likely to think the incident was trivial and that it was a private matter while women were more likely to say they were afraid of reprisal, particularly when the offender was their partner.

To our knowledge, no one has examined changes over time in the reporting of domestic assault. There are two reasons to expect a change in police notification. First, publicity about the issue of domestic violence in the last thirty years may have increased the rates of reporting. Second, the introduction of mandatory arrest laws for domestic 
violence during this time period may have encouraged reporting, if the caller preferred to see the offender arrested (Bachman, 1995). On the other hand, mandatory arrest laws might discourage victims from calling if they do not want family member arrested (Buzawa \& Buzawa, 2003). Hotaling and Buzawa (2001) found that victims of domestic assault were much less likely than victims of other assaults to want the offender arrested. In addition, victims who have engaged in violence might be deterred from reporting if they anticipate that they will be arrested themselves.

\section{REPORTING SEXUAL ASSAULT}

Studies of police notification collected during the early 1970s found that victims of sexual assault were much less likely than victims of other violent crimes to call the police (e.g., Dukes \& Mattley, 1977; Hawkins, 1973; Hindelang \& Gottfredson, 1976). A more recent study, based on the NCVS, suggests that male victims are even less likely to report the crime than female victims (Pino \& Meier, 1999).

Research suggests that sexual assaults involving non-strangers are particularly unlikely to be reported (Hindelang \& Gottfredson, 1976; Lizotte, 1985; Williams, 1984). It is unclear, however, whether victims of sexual assaults are more reluctant to report the incident than victims of physical assaults when they know the offender. Perhaps the reluctance to report reflects more general inhibitions related to knowing an offender and it does not matter whether the assault has a sexual element. Only a comparison of reporting for sexual and physical assault will reveal whether sexual assaults by nonstrangers are particularly unlikely to be reported. 
Sexual assaults may be less likely to be reported to the police than physical assaults for a variety of reasons: (1) the embarrassment and stigma associated with the crime (Bachman \& Taylor, 1994); (2) perceptions by victims that they will not be believed or that the criminal justice system is ineffective (Feldman-Summers \& Ashworth, 1981; Fisher, Daigle, Cullen, \& Turner, 2003; LaFree, 1980); (3) perceptions that some incidents are not serious enough (Fisher et al., 2003); (4) ambiguity about what constitutes illicit sexual conduct (DeKeseredy \& Schwartz, 2001; Gavey, 1999; Russell, 1982); (5) less fear of future attack since sexual assaults are less likely to be repeated; (6) greater fear of reprisal if they do report (Amir, 1971; Singer, 1988; Fisher et al., 2003); and (7) less third party reporting because sexual assaults are much more likely to occur in private.

These inhibitory factors may be particularly important when the sexual assault victim knows the offender. For example, Williams (1984) suggests that "the fact that a woman knows her rapist may encourage her to blame herself. She may feel that she 'led him on' and was not really raped, and that consequently there is no crime to report. Even when a woman identifies herself as a rape victim, she may fear that others will not believe she was raped if she knew the man”. (p. 460)

Note that at least two other factors might lead to higher reporting of sexual assault than physical assault. First, sexual assaults are typically considered more serious than physical assault, particularly when they are committed by strangers. Second, sexual assaults are less likely to involve a provocation by the victim; they are typically predatory, not dispute-related crimes. Victims might be more reluctant to report a physical assault because they share culpability. 
We are not aware of any statistical studies that have examined reasons for not reporting sexual assaults or examined whether the inhibitions for reporting sexual assault are different than those for physical assault. Perhaps the victims' fear or reprisal, beliefs about the efficacy of the criminal justice, or anticipation that the authorities will not believe their charges are just as likely to inhibit the reporting of physical assaults. Perhaps these factors inhibit the reporting of both physical and sexual assaults if the victim knows the offender.

A variety of legal, political, and cultural reforms were initiated in the early 1970s whose purpose, in part, was to encourage victims of sexual assault to call the police (Berger, Searles, \& Newman, 1988; Epstein \& Langenbahn, 1994; Spohn \& Horney, 1992). There is some speculation in the literature that these reforms, or the publicity surrounding the reforms, have resulted in increased reporting, especially among those attacked by somebody they know (e.g., Bachman, 1993; Bryden \& Lengnick, 1997; Spohn \& Horney, 1992).

Evidence that the reforms or the publicity associated with them had a causal effect is lacking. However, the evidence is fairly clear that rates of police notification for rape have increased, especially among those attacked by somebody they know (Bachman, 1998; Jensen \& Karpos, 1993; Orcutt \& Faison, 1988). For example, in the most recent study, Baumer, Felson, and Messner (2003) analyzed changes in rape reporting using the NCVS (1992-2000) and the earlier version of that survey, the National Crime Survey (1973-1991). The data sets and time periods were analyzed separately because of the change in survey questions. They found that rates of police notification for incidents of rape have increased since the early 1970s. During the 1970s and 1980s the increase in 
reporting was due to changes in third party reporting and changes in victim reporting of spousal rape. During the 1990s, the rates of change accelerated and broadened in scope: there was an increase in both victim and third party reporting of rapes committed by strangers as well as non-strangers. By the early 1990s, rapes committed by non-strangers were apparently just as likely to be reported to the police as rapes committed by strangers.

These studies only study the reporting of sexual assaults. They did not explore the possibility that the trends they found reflected general trends in the reporting of violent crime. Evidence from victimization surveys suggests that the reporting of violent crime in general increased slightly from 1973-1992 (Bureau of Justice Statistics, 1993) and from 1992-2000 (Hart \& Rennison, 2003). Perhaps trends in the reporting of sexual assault reflect a general trend in reporting rather than cultural or legal changes in response to sexual assault.

\section{THE CURRENT STUDY}

In this study we examine whether police notification depends on gender, victimoffender relationship, and type of assault. We examine both victim and third party reporting because of evidence that they sometimes respond differently (e.g., Felson et al., 1999). We examine both sexual assault and physical assault in order to determine whether there are special inhibitions about reporting sexual assaults by non-strangers or whether the pattern reflects more general inhibitions about reporting any violent offender the victim knows. Because we take a multivariate framework, we can disentangle the 
effects of type of crime from the effects of victim's gender, offender's gender, and social relationship. We hypothesize that the following assaults will have low rates of reporting:

(H1) the offender is a partner or family member (rather than a stranger or someone else the victim knows). This hypothesis follows from Black’s (1976) ideas on relational distance. Intermediate levels of reporting should be observed when the offender is someone else the victim knows.

(H2) women assaulted by male partners. This follows from the literature suggesting that there are special barriers that inhibit a woman from reporting such as her fear of reprisal or belief that her charges will not be taken seriously.

(H3) women assaulted by men. This follows from Black’s (1976) ideas on the availability of law to victims with lower status than offenders.

(H4) sexual assaults committed by nonstrangers. This hypothesis follows from the sexual assault literature which emphasizes special difficulties in prosecuting these cases. It is also possible that sexual assaults generally are less likely than physical assaults to be reported.

(H5) sexual assaults and couple violence that happened before the 1980s. We examine whether reporting increased during the 1980s and 1990s, when public attention to these crimes increased and when changes were instituted in the legal system that may have facilitated prosecution. This hypothesis implies a statistical interaction between time period and sexual assault and between time period and couple violence. 
We also examine the reasons victims give for their decision not to call the police. If victims are particularly unlikely to report assaults by their partners or sexual assaults by people they know, these analyses may reveal why. We examine the following inhibitory beliefs among nonreporting victims: embarrassment; fear of reprisal; the belief that the police will not believe their charges; the belief that the police would be ineffective; and the belief that the offense was too minor. We examine, for example, whether fear of reprisal inhibits women from reporting assaults by their male partners, and whether embarrassment inhibits the reporting of sexual assault and assaults by partners and family members.

In our analyses we include controls for situational characteristics of the crime that might be associated with reporting. The seriousness of the offense is indicated by whether the offender injured the victim, used a weapon, had assaulted the victim before, or assaulted the victim in his or her home. Prior research suggests that incidents that involve injury and weapon use, and that occur in the home, are more likely to be reported (Felson et al., 2002). We also control for variables that could affect culpability, i.e. whether the victim was the first to use violence, and whether the offender and victim were using alcohol and drugs at the time of the offense. Finally, we control for standard demographic variables, such as the age, race, education, and income of the victim. Previous research finds that victims are more likely to report assaults if they are older and Black (Felson et al., 2002). 


\section{METHODS}

The National Violence Against Women Survey includes data collected in 19951996 from a nationally representative sample of 8,000 women and 8,000 men, age 18 and over (see Tjaden \& Thoennes, 2000). A computer-assisted telephone interview was conducted with each respondent, asking about experiences with violence. We used items in which respondents were asked about incidents of physical assault during adulthood and sexual assaults since childhood. However, an examination of the data reveals that some respondents described incidents of physical assault that occurred when they were teenagers, and a few described childhood victimizations.

For physical assaults, respondents were asked whether anyone had: "Thrown something at you that could hurt you? Push, grab or shoved you? Pulled your hair? Slapped or hit you? Kicked or bite you? Choked or attempted to drown you? Hit you with some object? Beat you up? Threatened you with a gun? Threatened you with a knife or other weapon besides a gun? Used a gun on you? Used a knife or other weapon on you besides a gun?” For sexual assaults, respondents were asked: “Has a man or boy ever made or tried to make you have sex by using force or threatening to harm you or someone close to you? Has anyone, male or female, ever made or tried to make you have oral sex by using force or threat of harm? Has anyone ever made or tried to make you have anal sex by using force or threat of harm? Has anyone, male or female, ever put fingers or objects in your vagina or anus against your will by using force or threats?”

Respondents were asked about the most recent incidents and could report up to six physical assaults by different offenders and six sexual assaults by different offenders. If a victim was assaulted multiple times by the same offender, only the most recent 
incident was recorded. The sample includes a sufficient number of male victims of sexual assault $(n=226)$ to disentangle the effects of gender and sexual assault. On the other hand, incidents involving same-sexed couples were eliminated from analyses, since their number is insufficient for analysis $(\mathrm{n}=30)$. We also excluded 741 cases including 259 cases with no information on the assault, 293 cases with unknown police notification, and 47 cases that were reported by the offender. The final sample includes 6291 physical assaults and 1787 sexual assaults reported by 6026 respondents.

We estimate all equations using Stata software, treating the incident as the unit of analysis. Because many respondents reported more than one incident, the assumption of independence of errors across observations is violated. We use Stata's Cluster adjustment to address this issue. Effects on victim and third party reporting are estimated using multinomial logistic regression.

We also analyze the victims' reasons for not reporting. A potential problem is that nonreporting victims might not be representative of the entire population of victims (see Greene, 2003; Heckman, 1979). To address the problem of selection bias, we estimate the equations for reasons using maximum-likelihood probit estimation with selection.

\section{$\underline{\text { Measurement }}$}

Our main dependent variables are based on responses to two questions: "Was this incident reported to the police?" and, for those who answered "yes”, "Who reported the incident to the police?” From these responses, we constructed a three-category dependent variable: victim reported the incident, third party reported the incident; and no one reported the incident (the comparison category). 
Our other dependent variable is the respondent's reasons for not reporting the incident. Nonreporting victims were asked “Is there a reason why didn’t report the incident to the police?” Victims could provide up to four different reasons per incident. Our analyses are based on the following reasons: (1) “didn’t think police could do anything;” (2) “wouldn’t be believed, incident would be viewed as my fault;” (3) “too minor, not a police matter, not serious enough, not a crime;" (4) "fear of offender, fear he/she would get even, scared;” (5) "shame, embarrassment, thought it was my fault;” and (6) “did not want anyone to know about it”. We collapsed the last two categories since they both concern embarrassment and concern for image. We then created five dichotomous variables, coded 1 if they mentioned a particular reason and 0 if they did not.

The principal independent variables of interest include whether the offense was a sexual or physical assault, the relationship between the offender and victim, the decade the offense was committed, the gender of the offender, and the gender of the victim. Victim-offender relationship is coded as either partner (spouses, former spouses, partners, and former partners), other family (parents, children, uncle, aunt, cousin, brother, sister, “in-laws”), other known (i.e. friend, date, and acquaintance) or stranger (the reference category). Preliminary analyses suggest that it is unnecessary to code couples in more detail since the effects are not significantly different. Also, note that people that are known by sight only are coded as strangers on this survey.

The categories for the rest of the variables control variables are presented in Table 1. Victim precipitation is based on whether the victim was the first to use or threaten to use violence. The only continuous variable is level of education. It is coded from 1 to 7 , 
where 1 is "no schooling”, 2 is " $1^{\text {st }}-8^{\text {th }}$ grade", 3 is "some high school”, 4 is "high school graduate”, 5 is “some college”, 6 is " 4 years college degree”, and 7 is "postgraduate”. The victim's annual income is based on total household income in 1995, from all sources, before taxes. The decade the offense was committed is based on an item in which victims were asked how long ago the incident happened; we subtracted the number of years reported from the year of the survey. To preserve sample size, we created dummy variables to handle missing data for independent variables with significant missing data.

Our analyses of time trends depend on the ability of respondents to remember events that may have occurred in the distant past. However, physical and sexual assaults are memorable events (see Woltman \& Cadek, 1984, for a comparison of memory of violent crime and property crime). While most respondents should have no trouble remembering objective facts, they may have difficult remembering their reasons for not calling the police. Respondents are given the opportunity to say that they "don't know" in response to the questions, but they may think they remember but are in error.

However, these mistakes are likely to produce random measurement error, i.e., they are not likely to be systematically related to victim-offender relationship or gender, our central variables of interest. The time variable is more worrisome. It is possible that the sample of incidents in the distant past includes a higher incidence of more serious incidents since they are more likely to be remembered. Our controls for injury and weapon use in our equations should address this potential sampling bias, but there could be others. 


\section{RESULTS}

Descriptive statistics are presented in Table 1. They show that victims are almost twice as likely to report incidents as third parties, but that only about one out of four incidents are reported. Less than a quarter of the incidents involved a sexual assault. Victims are less likely to have been assaulted by other family members than by partners, strangers, and other known offenders (friends, dates, and acquaintances). The most common reason victims give for not reporting the assault is that it was too minor. Finally, 2/3 of the incidents occurred since 1980.

Insert Tables 1 and 2 about here

\section{Determinants of Reporting}

The multinomial logistic regression coefficients are presented in Table 2. The equation includes three multiplicative terms representing statistical interactions. Recall that we hypothesized that police notification would be particularly unlikely when women are assaulted by their partners (H2), when women are assaulted by men (H3), and when sexual assaults are committed by someone the victim knows (H4). Interactions involving time period will be discussed later.

The hypothesis that women are particularly unlikely to report their partners (H2) is not supported. We do observe a significant male x couple interaction $(b=-.789)$, but it is not in the predicted direction. It is men who are particularly unlikely to report assaults by their partner. In general, however, police notification is much less likely if the offender and victim know each other in any way. These main effects are quite strong. For example, the odds that victims will notify the police are about 5 times lower if the 
offender is a family member rather than a stranger (odds ratio of .203). Victim reporting levels for different relationships are presented in Figure 1.

Figure 1 about here

We do observe some variation in the strength of reporting for different types of non-strangers. We changed in the comparison category to other known in analyses not presented to examine statistical significance. The results provide mixed support for the hypothesis that reporting increases with relational distance (H1). Victims are just as likely to report partners as other known offenders. They appear to be less likely to report family members than other known offenders, but the difference is not quite statistically significant $(\mathrm{p}=.07)$. For third party reporting, the coefficients are in line with Black's (1976) prediction: more strongly negative for partners and other family members than for other known offenders. However, only the difference between partners and other known is statistically significant $(\mathrm{p}=.04)$.

In testing the hypothesis regarding sexual assaults by nonstrangers (H4) we initially included three interaction terms involving sexual assault x partners, family members, and other known offenders. The coefficients for the terms involving partner and family members were close to zero and statistically insignificant indicating that sexual assaults involving partners and family members are just as likely to be reported as sexual assaults by strangers. However, we did find a statistical interaction between sexual assault and other known offenders. The results, displayed in Figure 2, indicate that both victims and third parties are particularly unlikely to report sexual assaults involving other known offenders. These are the types of assaults typically referred to as “acquaintance rape.” 
Figure 2 about here

We also examined whether the reporting of sexual assaults depends on the victim's gender. An interaction term for sexual assault by male victim was added to the equation in Table 2 (not presented in tabular form). The coefficients for victim and third party reporting were opposite in sign and neither were statistically significant $(b=-.62$; $p$ $=.25 ; \mathrm{b}=.58 ; \mathrm{p}=.08)$.

The hypothesis that men's assaults on women are particularly unlikely to be reported (H3) is not supported. We do observe a statistical interaction for victim reporting, but the interaction is not in the predicted direction. The interaction, depicted in Figure 3, shows that women are particularly likely to report assaults committed by men and men are particularly likely to report assaults committed by women. We only observe a main effect for gender of victim on third party reporting. Third parties are more likely to report violence against women, regardless of the gender of the offender.

Figure 3 about here

The results in Table 2 also show that police notification is more likely if the incident is more serious. Thus, victims are more likely to call the police if they were injured, the offender used a weapon, or if they were assaulted at home. Third parties are more likely to report incidents that involve injuries or weapons.

Variables associated with culpability of the victim also affected reporting. Thus, victims who were the first to use violence or who were drinking alcohol or using drugs at the time were less likely to call the police. Third parties were also less likely to report if the victim was drinking alcohol or using drugs. On the other hand, if the offender was 
drinking alcohol or using drugs, both victims and third parties were more likely to report the incident.

The demographic variables also had some effects. Victims who are Black or older are more likely to call the police while third parties are more likely to report incidents if the victim is less educated. Finally, victim reporting, but not third party reporting, significantly increased during the 1990s. There is some evidence of an increase in the 1980s but it is not statistically significant.

\section{Changes over Time}

Recall that we predicted that the reporting of partner and sexual assault would increase in the 1980s and 1990s because of changes in the legal treatment of these crimes and changes in public attitudes (H5). For these analyses we added multiplicative terms involving either partner violence or sexual assault and the decade the incident occurred. None of the multiplicative terms were statistically significant (Results not shown but available upon request). The results do not support the hypothesis that the rate of reporting of partner and sexual assault increased during the 1980s and 1990s, relative to the reporting of other assaults.

In analyses not presented we examined other interactions involving decade to determine whether there were changes in the reporting of certain types of crime. For example, we examined interactions between decade and gender of victim, nonstrangers, weapon use, and injury. A few interactions were statistically significant but no patterns were observed. Finally, we found no change over time in the reporting of sexual assaults by nonstrangers. 


\section{$\underline{\text { Reasons for Not Reporting Physical and Sexual Assaults }}$}

We analyze the reasons victims gave for not reporting the incident in Table 3.

The analyses are based on victims who did not report the incident and includes a correction factor that takes into account sample selection for nonreporters. We include the same control variables in the equation as we did before, but we only present our main variables of interests.

Results in Table 3 suggest four reasons why victims of sexual assault are less likely than victims of physical assault to report the incident. Victims of sexual assaults are more likely to say that they did not notify the police because: (1) they didn't think the police could do anything; (3) they wouldn’t be believed; (3) they were afraid of reprisal; and (4) they would be embarrassed. On the other hand, they are less likely to say that sexual assaults were too minor to report.

We also observe statistical interaction involving sexual assault $\mathrm{x}$ other known, indicating that victims respond differently to what are sometimes called "acquaintance rape.” Victims are particularly likely to be too embarrassed to report sexual assaults committed by other known offenders. Also, victims are more likely to say that sexual assaults by acquaintances are too minor compared to sexual assaults by strangers.

Victims are not more likely to view domestic violence as too minor to report. Rather, victims assaulted by other people they know were more likely to think the incident was too minor to report. In addition, we observe a significant gender interaction. The pattern indicates that women are particularly unlikely to consider assaults by men as too minor to report. 
We find no support for the hypothesis that women are particularly likely to fear reprisals from male partners. The gender and partner effects are additive: both men and women are more likely to fear reprisal from male offenders and from partners.

Victims are more likely to say that they did not think the police could do anything if the offender was a partner (vs. a stranger). They are more likely to think that they “wouldn’t be believed” if the offender was a family member. Victims are not particularly reluctant to report domestic violence because of embarrassment.

\section{DISCUSSION}

Our results suggests that victims are less likely to report an assault if they know the offender in any way; if they are men and the offender is their female partner; if the offender is someone of the same gender; if they were sexually assaulted, particularly if the offender is a friend, date, or acquaintance. Third parties are less likely to report violence involving people who know each other in any way, particularly if the victim and offender are a couple. They are more likely to report violence against women and less likely to report sexual assaults than physical assaults, particularly when the offender is a friend, date, or acquaintance. We now discuss these results in more detail.

\section{$\underline{\text { Social Relationships }}$}

The effects of social relationship on victim reporting observed here are consistent with evidence from some research (e.g. Block 1974; Felson 1996; Gartner \& Macmillan, 1995), but inconsistent with research based on the NCVS (Felson, 1999). The former find that victims are less likely to report violence by people they know while the latter 
does not. The reason for the discrepancy between the NCVS-based study and the current study is unclear. However, neither study finds statistically significant differences in victim reporting between assaults committed by partners and family members and assaults committed by other nonstrangers. The results are consistent in showing that victims are not more likely to tolerate domestic violence than violence by other people they know.

We do observe one exception to this pattern: men are particularly unlikely to report assaults by their female partners. While both women and men are less likely to report partner violence than stranger violence, women are more likely to report partner violence than men. This finding does not support claims that women have special inhibitions about reporting their male partners (e.g., Belknap, 2001; Dobash \& Dobash, 1998).

We cannot determine why women are more likely to report their partners than men. We found no statistical interactions between gender and partner in our analyses of reasons for nonreporting. Felson et al. (2002) analyses of victims’ reasons for calling suggests that women are more concerned about protecting themselves, and that seeking protection is much more likely to motivate women to report violence than fear of reprisal is to inhibit them. They point out that discussions of victim reporting have ignored the possibility that there may be greater incentives for a victim to report an incident by someone they know and that these incentives may offset the costs of reporting.

We had limited success generally in explaining why the victims are more reluctant to report offenders they know than strangers. If the offender was a partner, victims were more likely to fear reprisal and think that the police could not do anything to 
help. If the offender was a family member they thought their charges would not be believed. If the offender was someone else they knew, they were more likely to think the incident was too minor to report. Apparently, victims have a variety of reasons for not reporting people they know, and those reasons vary somewhat depending on their relationship to the offender.

The effects of social relationship on third party reporting are generally consistent with prior research based on the NCVS (Felson et al., 1999). The evidence shows that third parties are less likely to report couple violence than stranger violence. However, we cannot determine whether effects on third party reporting reflect a reluctance to report an assault or a lack of knowledge that the assault occurred, since we do not know whether third parties witnessed the incident or otherwise knew about it. Previous research based on the NCVS suggests that both factors are operating (Felson et al., 1999). The reluctance of third parties to intervene in violent incidents involving couples has also been demonstrated in experimental research (Shotland \& Straw, 1976). Witnesses were less likely to intervene themselves in a staged fight involving a couple than a fight involving strangers because they were less likely to believe that the victim wanted help or that she was likely to get hurt.

The results provide mixed support for Black’s (1976) hypothesis that reporting increases with relational distance. Relational distance was more clearly related to third party reporting than victim reporting. The evidence suggests that the victim's closeness to the offender is a factor in reporting decisions, but that the relationship is not linear. Further, we believe that Black’s structural approach, which ignores social psychological factors, is not adequate for understanding the decision making process. It is important to 
examine the incentives and costs for reporting and how they vary depending on the victim's relationship to the offender. In addition, the key difference for reporting is whether the offender is someone the victim knows at all.

The results do not support the hypothesis that reporting of violence depends on the relative status of offender and victim. Men's violence against women is not particularly unlikely to be reported. In fact, third parties are more likely to report violence against women. This finding is consistent with prior research using the NCVS (Felson et al., 1999) and it is consistent with evidence that third parties take special efforts to protect women (see Felson, 2002, for a review). However, it is important to note that we only examine the net effects of gender. The types of violent crime that target women, sexual assault and nonstranger violence, both tend to be underreported. This pattern of victimization leads to the concealment of violence against women and increases their vulnerability.

Our hypothesis on status effects was based on the assumption that women have lower status than men in the United States. Some research on gender stereotyping has questioned this assumption (see Eagly \& Mladinic, 1994, for a review). However, our analyses of the effects of race and socioeconomic status do not support the idea that lower status victims are reluctant to call the police either. Consistent with other research, we found that the victim's education and income are unrelated to reporting and that black victims are more likely to report assaults (Felson et al., 2002). Moreover, reporting decisions are much more highly influenced by the use of alcohol and drugs by offenders and victims than their social status. 
The finding that victims are more likely to report assaults committed by someone of the opposite gender is also consistent with the literature (Felson, 1996; Felson et al., 1999). Women may be more likely than men to report male offenders because of sex differences in relative strength and the importance of protection as a motive for calling the police. The tendency for men to report female offenders (more than they report male offenders) is particularly interesting. Perhaps some men feel that they should be able to defend themselves against another man and that they will be perceived as cowardly if they call the police. On the other hand, there is no honor in fighting a woman since it is not seen as a "fair fight." Men lose face whether they win or lose, so they may prefer to rely on the police. Selection is also a potential explanation: women who assault men may be particularly violent offenders.

\section{$\underline{\text { Sexual assault }}$}

Our findings are consistent with the literature in showing that sexual assaults are less likely to be reported than physical assaults. The reluctance of victims to report sexual assault does not appear to reflect a gender bias since it is observed with controls for gender, and since we do not observe a significant gender by sexual assault interaction. The results suggest that it is the nature of the crime not the gender of participants that inhibits the reporting of sexual assault.

The analyses of reasons help explain why victims are less likely to report sexual assaults than physical assaults. Victims of sexual assault are less likely to report the incident for four reasons: (1) they were more likely to be embarrassed; (2) they were more likely to fear reprisal; (3) they were more likely to think the police would not 
believe them; and (4) they were more likely to believe the police would be ineffective.

All of these factors have been mentioned in the sexual assault literature as factors inhibiting the reporting of sexual assault. Note that victims underreport sexual assault in spite of the fact that they view them as more serious.

Sexual assault committed by friends, dates, and acquaintances are particularly likely to go unreported. The results support the literature suggesting that there are special inhibitions about reporting sexual assault involving acquaintances. The analyses of reasons suggests that victims are particularly unlikely to report these assaults because of embarrassment and because they think the incidents were too minor or not a crime (in comparison to sexual assaults by strangers). The perception that some of these assaults were too minor to report is consistent with evidence that many victims of "acquaintance rape” do not consider themselves crime victims (Koss, Gidycz, \& Wisniewski, 1987).

\section{$\underline{\text { Time Trends }}$}

The evidence argues against the idea that cultural and legal changes in the treatment of domestic violence and sexual assault in the last two decades affected police notification. We observed no evidence that trends in reporting these crimes were different from trends in reporting other violent crimes. Thus we find no support for the idea that mandatory arrest laws, changes in the legal treatment of sexual assault cases, or the publicity associated with these crimes had any effect on reporting. We do observe a statistically insignificant increase in general reporting by victims during the 1980s and a significant, substantial increase in the early 1990s. The results are consistent with evidence from the NCS and the NCVS showing that the reporting of violent crime in 
general has increased since 1973 (Bureau of Justice Statistics, 1993, 2000). They suggest that the increases in reporting of rape over time that have been consistently reported in the literature (e.g., Baumer et al., 2003) may reflect a more general phenomenon.

In general, our conclusions about time trends must be more tentative than our other conclusions because of the possible impact of victim's memory. Evidence suggests that incidents in the past are more likely to have been forgotten if they were not reported to the police (Woltman \& Cadek, 1984). If this selection bias exists, incidents that are remembered from the distant past would be more likely to be reported than incidents forgotten. However, we found that more recent incidents are more likely to be reported. Perhaps the effects of recency would have been stronger without this bias. In general, our finding of mostly additive effects involving year of incident suggests that the variables that predict reporting are similar whether incidents occurred recently or long ago. If memory biases were operating we should have observed statistical interactions involving year of incident.

In sum, theoretical discussions that emphasize inhibitions about reporting family members or barriers to women cannot explain the reporting patterns that we observe in this study. Our results suggest that the reluctance to report sexual assaults reflects the nature of the crime not the victim's gender. Inhibitions about reporting domestic violence and sexual assault by non-strangers reflect a more general pattern: violence is less likely to be reported if the victim knows the offender in any way. Increases in the reporting of sexual assault and domestic violence over time also reflect a more general pattern: an increase in the reporting of all types of assaults. Thus our results are consistent with a 
growing body of research that shows the utility of studying the causes and consequences of domestic violence and violence against women in the context of violence generally (e.g., Felson, 2002). By examining this larger context, researchers can discover how these crimes are different and they can avoid what might be called "an over-specialized conception of violence.” 


\section{REFERENCES}

Amir, M. (1971) Patterns of forcible rape. Chicago, IL: University of Chicago Press.

Avakame, E. F., Fyfe, J.J., \& McCoy, C. (1999) Did you call the police? What did they do? An empirical assessment of Black’s theory of mobilization of law. Justice Quarterly, 16, 765-792.

Bachman, R. (1993) Predicting the reporting of rape victimizations: Have reforms made a difference? Criminal Justice and Behavior, 20, 254-270.

Bachman R. (1995) Police involvement in domestic violence: The interactive effects of victim injury, offender's history of violence, and race. Violence and victims, 10, 91-107

Bachman, R. (1998) The factors relating to rape reporting behavior and arrest: New evidence from the National Crime Victimization Survey. Criminal Justice and Behavior, 25, 8-29.

Bachman, R., \& Taylor, B. M. (1994) The measurement of family violence and rape by the redesigned National Crime Victimization Survey. Justice Quarterly, 11, 499512.

Baumer, E. P., Felson, R. B., \& Messner, S. F. (2003) Changes in police notification for rape, 1973-2000. Criminology, 41, 841-872

Belknap, J. (2001) The invisible woman: Gender, crime, and justice (2nd ed.). Belmont, CA: Wadsworth.

Berger, R. J., Searles, P., \& Neuman, W. L. (1988) The dimensions of rape reform legislation. Law \& Society Review, 22, 329-357.

Black, D. J. (1976) The behavior of law. New York: Academic Press. 
Block, R. (1974) Why notify the police: The victim's decision to notify the police of an assault. Criminology, 11, 555-569.

Bryden, D. P., \& Lengnick, S. (1997) Rape in the criminal justice system. Journal of Criminal Law \& Criminology, 87, 1194-1377

Bureau of Justice Statistics (1993) National Crime Victimization Survey, 1972-1992. U.S Department of Justice. Bureau of Justice Statistics. Washington, DC: USGPO. Bureau of Justice Statistics (2000) National Crime Victimization Survey, 1992-2000. U.S Department of Justice. Bureau of Justice Statistics. Washington, DC: USGPO.

Buzawa, E. S., \& Buzawa, C. G. (2003) Domestic violence: The criminal justice response ( $3^{\text {rd }}$ Edition). Sage Publications.

DeKeseredy, W. S., \& Schwartz, M. D. (2001) Theoretical and methodological issues in researching violence against women: Definitional issues. In C. M. Renzetti, J. L. Edleson, \& R. Kennedy Bergen (Eds.) Sourcebook on violence against women (pp. 23-34). . Thousand Oaks, CA: Sage.

Dobash, R. E., \& Dobash, R. P. (1998) Rethinking violence against women. Thousand Oaks, CA: Sage.

Dukes, R. L., \& Mattley, C. L. (1977) Predicting rape victim reportage. Sociology and Social Research, 62, 63-84.

Eagly, A. H. \& Mladinic, A. (1994) Are people prejudiced against women? Some answers from research on attitudes, gender stereotypes, and judgments of competence. European Review of Social Psychology, 5, 1-35.

Espstein, J., \& Langenbahn, S. (1994) The criminal justice and community response to rape. Washington, D.C.: U. S. Department of Justice, National Institute of Justice. 
Feldman-Summers, S. \& Ashworth, C. D. (1981) Factors related to intentions to report a rape. Journal of Social Issues, 37, 53-70.

Felson, R. B (1996) Violent disputes and calling the cops: The role of chivalry and social relationship. Paper presented at the Annual Meetings of the American Sociological Association, August.

Felson, R. B (2002) Violence and gender reexamined. Washington DC: The American Psychological Association.

Felson, R. B., Messner, S. F., \& Hoskin, A. H. (1999) The victim-offender relationship and calling the police in assaults. Criminology, 37, 931-947.

Felson, R. B., Messner, S. F., Hoskin, A. H., \& Deane, G. (2002) Reasons for reporting and not reporting domestic violence to the police. Criminology, 40, 617-647.

Fisher, B. S., Daigle, L. E., Cullen, F. T., \& Turner, M. G. (2003) Reporting sexual victimization to the police and others: Results from a national-level study of college women. Criminal Justice and Behavior, 30, 6-38.

Frieze, I.H., \& Browne, A. (1989) Violence in marriage. In L.E. Ohlin \& M. H. Tonry (Eds.) Family violence. Chicago, IL: University of Chicago Press.

Gartner, R., \& Macmillian, R. (1995) The effect of victim-offender relationship on reporting crimes of violence against women. Canadian Journal of Criminology, 37, 393-429.

Gavey, N. (1999) I wasn’t raped, but...': Revisiting definitional problems in sexual victimization. In S. Lamb (ed.) New versions of victims: Feminists struggle with the concept (pp. 57-81). New York: New York University Press. 
Gottfredson, M. R., \& Gottfredson, D. M. (1980) Decision-making in criminal justice:

Toward the rational exercise of discretion. Cambridge: MA: Ballinger Publishing.

Greene, W. H. (2003) Econometric analysis (5 ${ }^{\text {th }}$ Edition). Upper Saddle River, NJ:

Prentice-Hall.

Hart, T. C., \& Rennison, C. (2003) Reporting crime to the police, 1992-2000. Bureau of

Justice Statistics. Special Report. US Department of Justice.

Hawkins, R. O. (1973) Who called the cops? Decisions to report criminal victimization.

Law \& Society Review, 7, 427-444.

Heckman, J. (1979) Sample selection bias as a specification error. Econometrica, 47, 153-161.

Herzberger, S.D. (1996) Violence within the family: Social psychological perspectives. Boulder, CO: Westview Press.

Hindelang, M. J., \& Gottfredson, M. (1976) The victim's decision not to invoke the criminal justice process. In W. McDonald (Ed.) Criminal justice and the victim. Beverly Hills, CA: Sage

Hotaling, G. T., \& Buzawa, E. (2001) An analysis of assaults in rural communities: Final report. Federal Grant \#MA0095-400, US Department of Justice, Office of Community Oriented Policing Services.

Jensen, G. F., \& Karpos, M. (1993) Managing rape: Exploratory research on the behavior of rape statistics. Criminology, 31, 365-385.

Koss, M. P., Gidycz, C. A., \& Wisniewski, N. (1987) The scope of rape: Incidence and prevalence of sexual aggression and victimization in a national sample of students in higher education. Journal of Consulting and Clinical Psychology, 55, 162-170. 
Koss, M. P., Goodman, L. A., Browne, A., Fitzgerald, L. F., Keita, G. P., \& Russo, N. F. (1994) No safe haven: Male violence against women at home, at work, and in the community. Washington, D.C.: American Psychological Association.

LaFree, G. (1980) Variables affecting guilty pleas and convictions in rape cases: Toward a social theory of rape processing. Social Forces, 58, 833-850.

Lizotte, A. J. (1985) The uniqueness of rape: Reporting assaultive violence to the police. Crime \& Delinquency, 31:169-190.

Orcutt, J. D., \& Faison, R. (1988) Sex-role change and reporting of rape victimization, 1973-1985. The Sociological Quarterly, 29, 589-604.

Pagelow, M.D. (1984) Family violence. New York: Praeger.

Pino, N. W. \& Meier, R. F. (1999) Gender Differences in Rape Reporting. Sex Roles, 40, 979-990.

Russell, D. E. (1982) The prevalence and incidence of forcible rape and attempted rape of females. Victimology, 7, 81-93.

Singer, S. I. (1988) The fear of reprisal and the failure of victims to report a personal crime. Journal of Quantitative Criminology, 4, 289-302.

Shotland, R.L., \& Straw, M. K. (1976) Bystander response to an assault: When a man attacks a woman. Journal of Personality and Social Psychology, 34, 990-999.

Spohn, C., \& Horney, J. (1992) Rape law reform: A grass roots revolution and its impact. New York: Plenum.

Straus, M. A., Gelles, R. J., \& Steinmetz, S.K. (1980) Behind closed doors: Violence in the American family. Garden City, NJ: Anchor Books. 
Tjaden, P., \& Thoennes, N. (2000) Extent, nature, and consequences of intimate partner violence: Finding from the National Violence against Women Survey. Washington: National Institute of Justice.

Williams, L. S. (1984) The classic rape: When do victims report? Social Problems, 31, 459-467.

Woltman, H., \& Cadek, G. (1984) Are memory biases in the National Survey associated with the characteristics of the criminal incident? In R. G. Lehnen \& W. G. Skogan The National Crime Survey: Working Paper. Volume 2: Methodological Studies (pp. 94-97). US Department of Justice. 
Table 1. Descriptive Statistics $(\mathrm{N}=8077)$

\begin{tabular}{|c|c|c|c|c|c|}
\hline & $\%$ & & $\%$ & & $\%$ \\
\hline 1. Dependent variables & & 3. Incident characteristics & & Location & \\
\hline Police Notification & & Type of offence & & Victim’s home & 37.4 \\
\hline Reported by victim & 15.1 & Sexual assault & 22.1 & Unknown location & 2.7 \\
\hline Reported by third party & 8.0 & Physical assault * & 77.9 & Other location $*$ & 59.9 \\
\hline Unreported & 76.9 & Gender of the offender & & Victim precipitation & \\
\hline Reasons for not reporting & & Men & 85.3 & Victim precipitation & 5.7 \\
\hline Police could not do anything & 4.8 & Women $*$ & 14.7 & Unknown victim precipitation & 4.7 \\
\hline Would not be believed & 2.7 & Victim - Offender Relationship & & No victim precipitation $*$ & 89.6 \\
\hline Too minor & 29.0 & Partner & 29.4 & Prior victimization & \\
\hline Embarrassment & 6.1 & Other family & 9.6 & 1-4 prior victimization & 24.4 \\
\hline \multirow[t]{2}{*}{ Fear of reprisal } & 5.0 & Other known & 29.9 & 5 and more prior victimization & 12.0 \\
\hline & & Stranger * & 31.1 & Unknown prior victimization & 9.1 \\
\hline 2. Victim characteristics & & Weapon used & & No prior victimization $*$ & 54.5 \\
\hline Gender & & Gun & 7.8 & Decade & \\
\hline Men & 51.2 & Other weapon & 12.8 & Before $1970 *$ & 12.9 \\
\hline Women * & 48.8 & Unknown weapon & 0.8 & 1970s & 18.1 \\
\hline Education (mean) & 4.8 & No weapon $*$ & 78.6 & 1980s & 30.7 \\
\hline Race/Ethnicity & & Injury to victim & & $1990 \mathrm{~s}$ & 33.8 \\
\hline Black & 9.5 & Physical injury & 28.3 & Unknown decade & 4.5 \\
\hline White * & 76.1 & Unknown injury & 0.7 & Victim's age at time of incident & \\
\hline Hispanic & 5.8 & No injury $*$ & 71.0 & 30 and older & 28.5 \\
\hline Other/Unknown race & 8.5 & Offender alcohol/drug use & & $18-29 *$ & 48.4 \\
\hline \multirow{9}{*}{$\begin{array}{l}\text { Income } \\
\text { High income (more than } \$ 50,000) \\
\text { Medium income }(\$ 20,000-\$ 50,000) * \\
\text { Low income (less than } \$ 20,000) \\
\text { Unknown income }\end{array}$} & & Offender used alcohol & 35.2 & Less than 18 & 13.4 \\
\hline & 11.8 & Offender used drugs & 12.0 & Unknown age & 9.7 \\
\hline & 36.4 & Unknown alcohol/drug use & 19.1 & & \\
\hline & 40.0 & No alcohol and no drug * & 33.7 & & \\
\hline & 11.8 & Victim alcohol/drug use & & & \\
\hline & & Victim used alcohol & 18.9 & & \\
\hline & & Victim used drugs & 2.8 & & \\
\hline & & Unknown alcohol/drug use & 1.8 & & \\
\hline & & No alcohol and no drug * & 76.5 & & \\
\hline
\end{tabular}

* Reference category 
Table 2. Multinomial Logistic Regression of Victim and Third Party Reporting (vs. Not Reporting)

\begin{tabular}{|c|c|c|c|c|c|c|}
\hline & \multicolumn{3}{|c|}{ Victim Reporting } & \multicolumn{3}{|c|}{ Third Party Reporting } \\
\hline & $b$ & $S E$ & $\begin{array}{l}\text { Odds } \\
\text { Ratio }\end{array}$ & $b$ & SE & $\begin{array}{l}\text { Odds } \\
\text { Ratio }\end{array}$ \\
\hline \multicolumn{7}{|l|}{ Incident Characteristics } \\
\hline Sexual offense & $-.329 *$ & .126 & .720 & .040 & .146 & 1.041 \\
\hline Partner & $-.964 *$ & .155 & .381 & $-1.481^{*}$ & .198 & .227 \\
\hline Other Family & $-1.595^{*}$ & .212 & .203 & $-1.202 *$ & .212 & .301 \\
\hline Other known & $-1.079 *$ & .112 & .340 & $-.955^{*}$ & .138 & .385 \\
\hline Male offender & .361 & .230 & 1.435 & -.050 & .248 & .951 \\
\hline Gun & 1.196* & .115 & 3.307 & $1.313^{*}$ & .135 & 3.717 \\
\hline Other weapon & $.629 *$ & .097 & 1.876 & $.855^{*}$ & .111 & 2.351 \\
\hline Unknown weapon & .225 & .419 & 1.252 & -.180 & .624 & .835 \\
\hline Physical Injury & $.999 *$ & .078 & 2.716 & $1.020^{*}$ & .092 & 2.773 \\
\hline Unknown injury & -.289 & .502 & .749 & .373 & .611 & 1.452 \\
\hline Offender used alcohol & $.456 *$ & .101 & 1.578 & $.669 *$ & .136 & 1.952 \\
\hline Offender used drugs & $.918^{*}$ & .121 & 2.504 & $.908^{*}$ & .161 & 2.479 \\
\hline $\begin{array}{l}\text { Unknown alcohol/drug use by } \\
\text { offender }\end{array}$ & $.819 *$ & .109 & 2.268 & $.822 *$ & .141 & 2.275 \\
\hline Victim used alcohol & $-1.146^{*}$ & .125 & .318 & $-.387 *$ & .128 & .679 \\
\hline Victim used drugs & $-.994 *$ & .249 & .370 & $-.838 *$ & .309 & .432 \\
\hline $\begin{array}{l}\text { Unknown alcohol/drug use by } \\
\text { victim }\end{array}$ & -.192 & .276 & .825 & -.168 & .344 & .845 \\
\hline Victim precipitation & $-.495 *$ & .171 & .610 & -.203 & .200 & .816 \\
\hline Unknown victim precipitation & $-.692 *$ & .227 & .501 & $-.717^{*}$ & .295 & .488 \\
\hline Home & $.293 *$ & .105 & 1.340 & .189 & .134 & 1.208 \\
\hline Unknown location & -.040 & .256 & .961 & -.890 & .480 & .411 \\
\hline 1-4 prior victimization & -.065 & .091 & .937 & -.215 & .122 & .807 \\
\hline 5 and more prior victimization & .222 & .118 & 1.249 & .221 & .149 & 1.247 \\
\hline $\begin{array}{l}\text { Unknown number of prior } \\
\text { victimization }\end{array}$ & .116 & .139 & 1.123 & -.116 & .189 & .890 \\
\hline $1970 \mathrm{~s}$ & -.105 & .175 & .900 & -.257 & .194 & .773 \\
\hline $1980 \mathrm{~s}$ & .231 & .164 & 1.260 & .115 & .185 & 1.122 \\
\hline $1990 \mathrm{~s}$ & $.629 *$ & .163 & 1.876 & .285 & .287 & 1.330 \\
\hline Unknown decade & $1.153 *$ & .311 & 3.168 & $-.891 *$ & .377 & .410 \\
\hline Victim 30 and older & $.356^{*}$ & .080 & 1.428 & .144 & .109 & 1.155 \\
\hline Victim less than 18 years old & $-.640 *$ & .164 & .527 & $.311^{*}$ & .136 & 1.365 \\
\hline Victim age unknown & $-.941 *$ & .292 & .390 & .173 & .256 & 1.189 \\
\hline \multicolumn{7}{|l|}{ Victim Characteristics } \\
\hline Men & .248 & .250 & 1.281 & $-.806^{*}$ & .331 & .447 \\
\hline Education & .013 & .035 & 1.013 & $-.117^{*}$ & .043 & .890 \\
\hline Black & $.273^{*}$ & .116 & 1.314 & .070 & .155 & 1.073 \\
\hline Hispanic & -.084 & .174 & .919 & .032 & .178 & 1.033 \\
\hline Other/Unknown race & .154 & .133 & 1.166 & .151 & .164 & 1.163 \\
\hline High income & -.038 & .123 & .963 & -.137 & .156 & .872 \\
\hline Low income & -.165 & .090 & .848 & -.135 & .108 & .874 \\
\hline Unknown income & .213 & .118 & 1.237 & -.012 & .151 & .988 \\
\hline \multicolumn{7}{|l|}{ Interactions } \\
\hline Male Victim x Partner & $-.789 *$ & .246 & .454 & .169 & .391 & 1.184 \\
\hline Male Victim x Male Offender & $-.824 *$ & .273 & .439 & .354 & .350 & 1.425 \\
\hline Sexual assault x Other known & $-.601 *$ & .236 & .548 & $-.569 *$ & .247 & .566 \\
\hline Constant & $-2.245 *$ & .337 & & $-1.810^{*}$ & .384 & \\
\hline
\end{tabular}

$* p<.05$ 
Table 3. Victim's Reasons for Not Reporting based on Probit Regression with Selection $(\mathrm{N}=6211)$

\begin{tabular}{|c|c|c|c|c|c|c|c|c|c|c|}
\hline & \multicolumn{2}{|c|}{$\begin{array}{c}\text { Police could } \\
\text { not do anything }\end{array}$} & \multicolumn{2}{|c|}{$\begin{array}{l}\text { Would not } \\
\text { be believed }\end{array}$} & \multicolumn{2}{|c|}{ Too minor } & \multicolumn{2}{|c|}{ Embarrassment } & \multicolumn{2}{|c|}{$\begin{array}{c}\text { Fear } \\
\text { of reprisal }\end{array}$} \\
\hline & $b$ & $S E$ & $b$ & $S E$ & $b$ & $S E$ & $b$ & $S E$ & $b$ & $S E$ \\
\hline Sexual offense & $.250^{*}$ & .077 & $.593 *$ & .087 & $-.892 *$ & .079 & $.488 *$ & .080 & $.586 *$ & .075 \\
\hline Partner & $.287 *$ & .116 & -.130 & .146 & .135 & .107 & -.021 & .110 & $.253 *$ & .116 \\
\hline Other Family & -.030 & .120 & $.268 *$ & .134 & .106 & .111 & .096 & .118 & -.050 & .123 \\
\hline Other known & -.033 & .083 & .186 & .103 & $.282 *$ & .088 & -.098 & .097 & .010 & .093 \\
\hline Male offender & .150 & .200 & .298 & .223 & $-.377^{*}$ & .102 & .070 & .157 & $.714^{*}$ & .268 \\
\hline Male victim & .165 & .228 & .100 & .262 & .029 & .117 & -.000 & .192 & .078 & .340 \\
\hline Male Victim * Partner & -.210 & .181 & .215 & .228 & .086 & .116 & -.340 & .207 & -.509 & .330 \\
\hline Male Victim * Male Offender & -.032 & .241 & -.389 & .280 & $.337^{*}$ & .130 & .135 & .174 & -.596 & .357 \\
\hline Sexual assault * Other known & .228 & .129 & .178 & .141 & $.280 *$ & .100 & $.385^{*}$ & .114 & -.075 & .127 \\
\hline
\end{tabular}

$* \mathrm{p}<.05$ 
Figure 1. Probability of Victim Reporting based on Victim-Offender Relationship

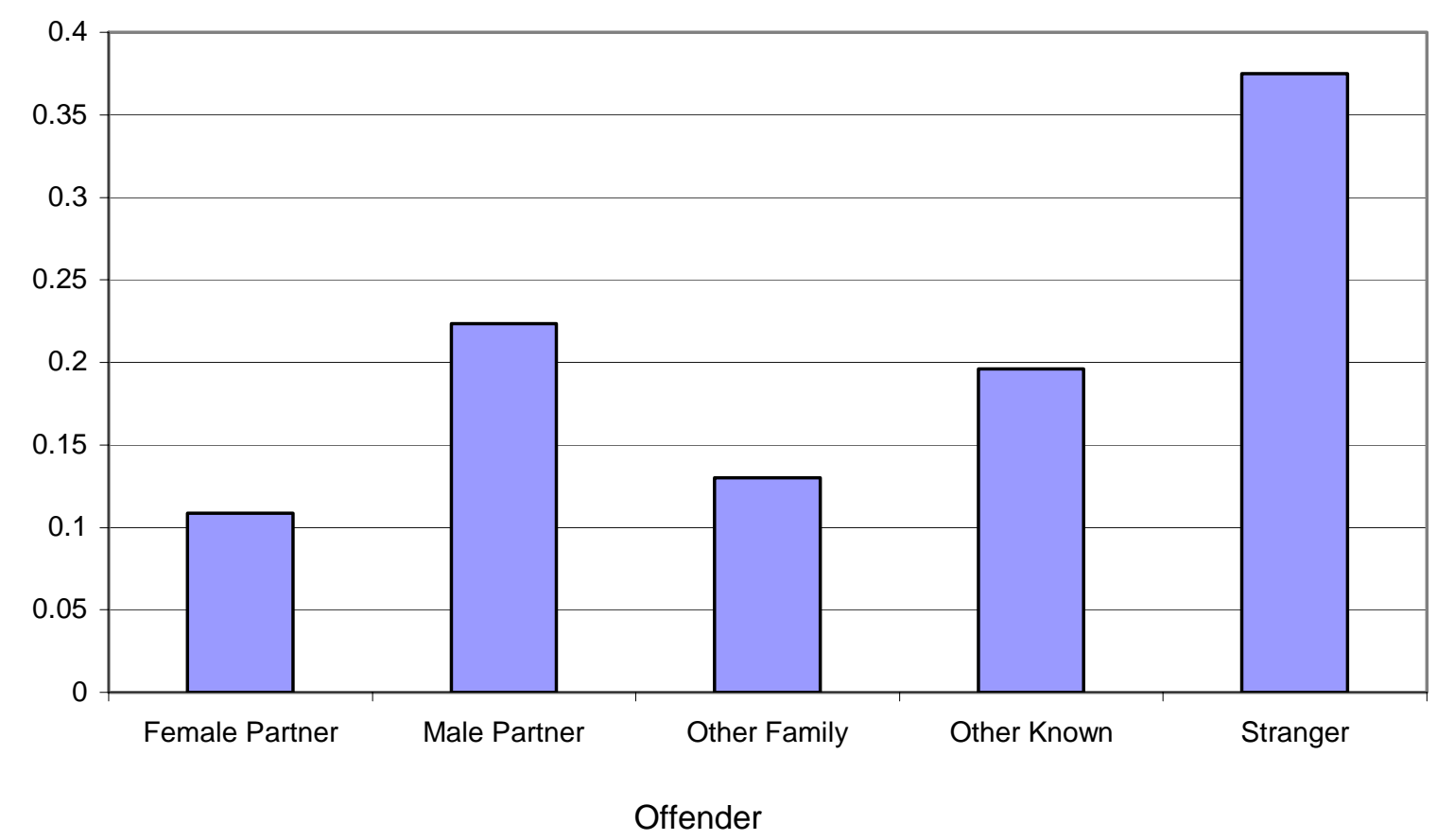

Note: Probabilities are calculated from the multinomial logistic equation in Table 2 using the following formula: $\mathrm{p}=(\exp [\mathrm{g} 1(\mathrm{x})]) /(1+\exp [\mathrm{g} 1(\mathrm{x})]+\exp [\mathrm{g} 2(\mathrm{x})])$

Estimates are based on incidents involving: male offender (reverse for female partner), physical assault, no alcohol or drug use by victim or offender, no weapon, victim injured, during the 1990s, outside victim's home, no prior incident; victim is a woman (reverse for female partner), high school graduate, White, $\$ 20,000$ - \$50,000 income, and 18-29 years old. 
Figure 2. Probability of Reporting of Physical and Sexual Assault committed by Strangers and Other Known Offenders

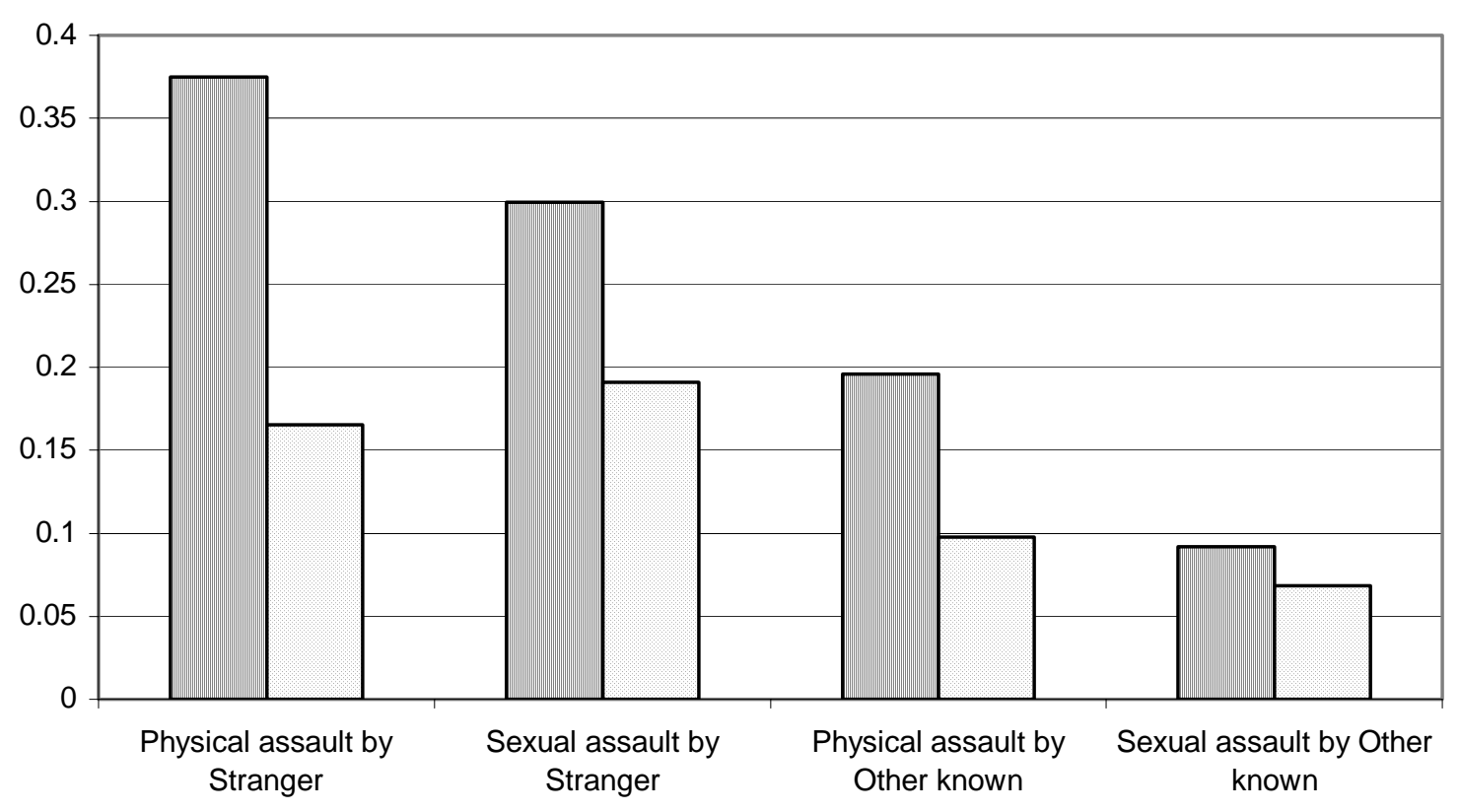

Bars with vertical lines are for victim reporting; bars with dots are for third party reporting

Note: Probabilities are calculated from the multinomial logistic equation in Table 2 using the following formula: $\mathrm{p}=(\exp [\mathrm{g} 1(\mathrm{x})]) /(1+\exp [\mathrm{g} 1(\mathrm{x})]+\exp [\mathrm{g} 2(\mathrm{x})])$

Estimates are based on incidents involving: male offender, no alcohol or drug use by victim or offender, no weapon, victim injured, during the 1990s, outside victim's home, no prior incident; victim is a woman, high school graduate, White, $\$ 20,000$ - $\$ 50,000$ income, and 18-29 years old. 
Figure 3. Gender Effects on Probability of Victim Reporting

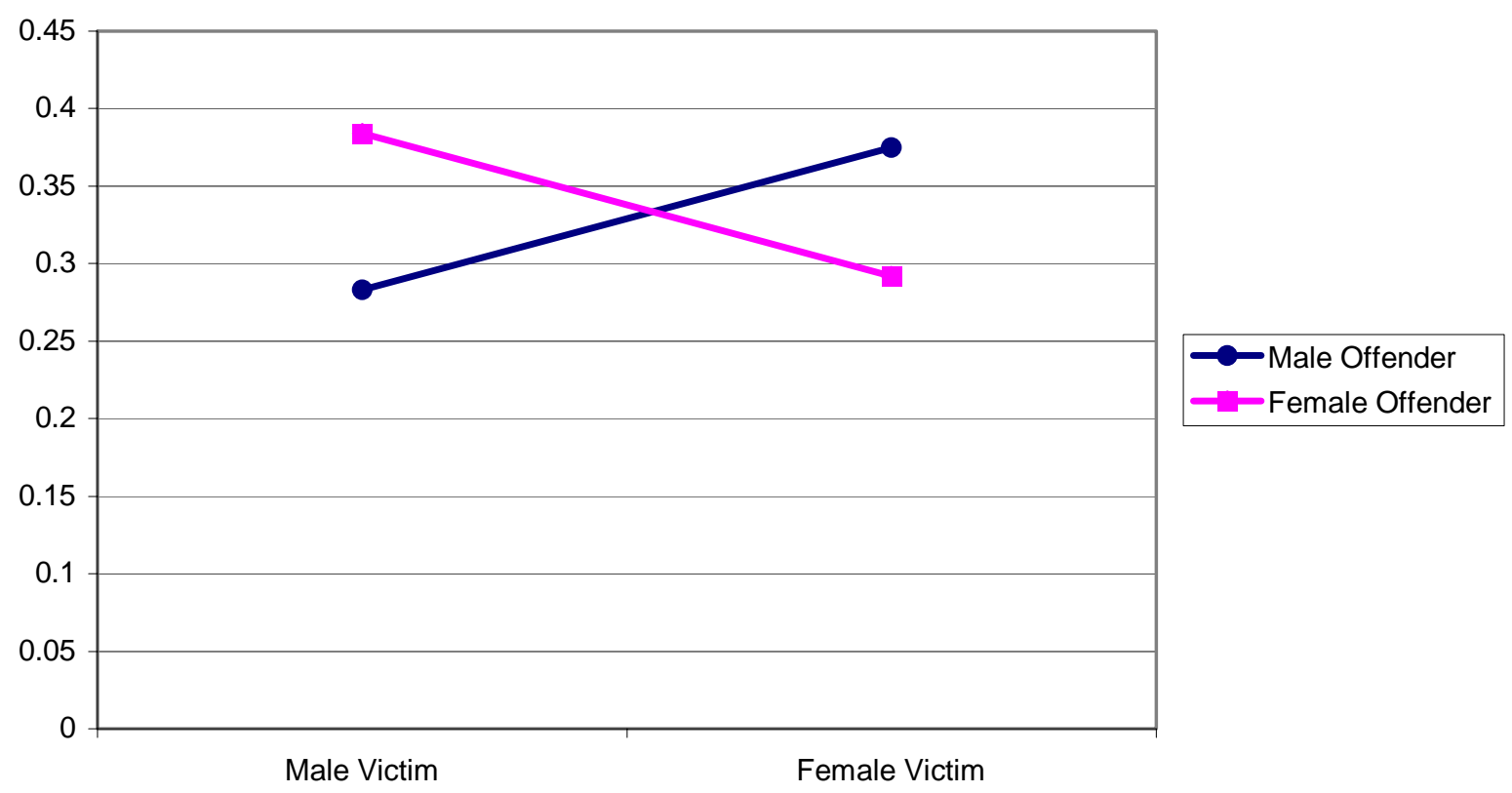

Note: Probabilities are calculated from the multinomial logistic equation in Table 2 using the following formula: $\mathrm{p}=(\exp [\mathrm{g} 1(\mathrm{x})]) /(1+\exp [\mathrm{g} 1(\mathrm{x})]+\exp [\mathrm{g} 2(\mathrm{x})])$

Estimates are based on incidents involving: physical assault, no alcohol or drug use by victim or offender, no weapon, victim injured, during the 1990s, outside victim's home, no prior incident; victim is high school graduate, White, $\$ 20,000$ - \$50,000 income, and 18-29 years old. 